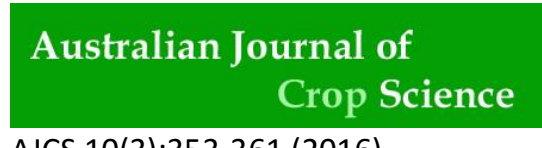

\title{
Crop rotation affects soybean performance in no-tillage system under optimal and dry cropping seasons
}

\author{
Mirianny Elena Freitas ${ }^{1}$, Luiz Carlos Ferreira de Souza ${ }^{1}$, Júlio Cesar Salton ${ }^{2}$, Ademar Pereira Serra $^{3}$, \\ Munir Mauad $^{1}$, Jorge Wilson Cortez ${ }^{1}$, Marlene Estevão Marchetti ${ }^{1}$
}

${ }^{1}$ Universidade Federal da Grande Dourados (UFGD), Post Graduation Program in Agronomy-Crop science, City of Dourados, State of Mato Grosso do Sul, Brazil

${ }^{2}$ Brazilian Agricultural Research Corporation (EMBRAPA), City of Dourados, State of Mato Grosso do Sul, Brazil

${ }^{3}$ Brazilian Agricultural Research Corporation (EMBRAPA), City of Campo Grande, State of Mato Grosso do Sul, Brazil

\section{*Corresponding author: ademar.serra@embrapa.br}

\begin{abstract}
The purpose of this research was to assess the crop rotation affects on agronomic traits of soybean in optimal (OCS) and dry cropping seasons (DCS). This research was carried out in 2010/2011 (OCS) and 2011/2012 (DCS) in a Rhodic Hapludox soil. The experimental design was set up in a randomized complete block and the treatments were arranged in a factorial 9 x 2 , consisting of 9 crop rotations systems and two cropping seasons, with four replications. The soybean (Glycine max cv. BMX-Potência RR) was sowed on October $20^{\text {th }} 2010$ and October $10^{\text {th }} 2011$ (spring-summer season) 20 days after the fall-winter cover crops desiccation. It was assessed in the R8 reproductive stage (Full maturation) the plant height, the height of the first pod insertion, number of pod per plants, number of branches per plant, number of seed per pod, 1000-grain weight and grain yield. It was observed that in drought stress (DCS), the number of branches decreased, this reduction was 36\% in relation to OCS. For the traits as plant height, first pod height, 1000-grain weight and yield, it was showed small values in DCS in contrast to OCS. It is feasible to introduce these cover crops in fall-winter season to make part of a crop rotation system. The number of pod per plant showed higher values under the crop rotation of corn/rapeseed/soybean, which showed highly associated with the soybean grain yield. This research brought options for cover crops system to be viable in no-till system with soybean in spring-summer season.
\end{abstract}

Keywords: Glycine max L.; grain yield; cover crops; soil conservation.

Abbreviation: DCS_dry cropping season; OCS_optimal cropping season.

Introduction

In tillage system, the use of disk arrow associated with the absence of crop rotation was applied in the last decade in the most part of cropland in Brazilian "Cerrado", nowadays the no-till system has been increased in these areas of agriculture in Brazil. The benefits of no-till system are large; furthermore it is important to emphasize the decrease of soil degradation, loss soil (Merten et al., 2015) and the increase in quality of physical, chemical and biological properties (Rosa et al., 2015). To turn a no-till system sustainable, it is quite important to have a system of crop rotation well defined. Although the no-till system has long-term of use, in many regions of the world it is necessary to define cover crops to be inserted in a crop rotation system, because without a crop rotation the no-till system cannot become sustainable (Congreves et al., 2015). It is possible to observe that there are absence of many scientific results about crop rotation system affects on soybean agronomic traits around the world. For farmers, the information about the cover crops to insert in a crop rotation system is very important, but sometimes this information is difficult to obtain. Despite the benefits that crop rotation offer, to be possible the recommendation of crop rotation for each particular case it is necessary the knowledge about its impact on crops in spring-summer season. The crop rotation system offers as advantages the improvement and maintenance of soil fertility, less pest, diseases and weeds (Nichols et al., 2015; Anderson, 2015). Agroecosystem in crop rotation shows several economic crops in a cropping season, which increases the chance in obtaining economic stability over the years (Fidelis et al., 2003). Although in the last decade the set-aside areas during the fall-winter season has decreased, these situations still occupy ample area in the south region of Brazil. The absence of cover crop during fall-winter season increase the change of soil erosion (TerAvest et al. 2015) and weeds (Nichols et al., 2015). The absence of cover crops decrease the potential of nutrient recycles in soil and can increase the leaching of $\mathrm{N}$ $\mathrm{NO}_{3}{ }^{-}$(Fraser et al., 2013). This way, cover crops are essential during fall-winter season to avoid depletion of the soil environment (Harasim et al., 2015).

To guarantee the success of the no-till system, it is important to define the species to make part of the crop rotation system (Argenta et al., 2001). Another important aspect is the need of enough aboveground dry matter to cover the whole soil surface during the cropping season. To maintain the soil 
surface covered by dry matter during the whole year is a challenge. Besides the quantity of aboveground dry matter, the persistence of aboveground dry matter is difficult due to the weather conditions that increase organic matter mineralization (Dumanski, 2015), high soil temperature and moisture. To face this challenge it is important to identify the crop species that can be introduced into the crop rotation system with the objective to increase the aboveground dry matter, that would not inhibit negatively the main crop cultivated in spring-summer season and bring economic gain during the fall-winter season. Thus, it is important to research about the crop species cultivated in fall-winter season that can be inserted in crop rotation system with the soybean as the main crop in spring-summer season. Nevertheless, it is important to keep in mind that the aboveground dry matter from crop species cannot diminish the agronomic traits and soybean grain yield. Thus, the crop species like sunflower, Brassica napus L., Carthamus tinctorius L., níger (Guizottia abyssinica) and forage turnip need researches to know the viability to be inserted in a crop rotation system without depleting the soybean grain yield. The purpose of this research was to assess the crop rotation affects on agronomic traits of soybean cultivated in spring-summer in optimal (OCS) and dry cropping seasons (DCS).

\section{Result and Discussion}

\section{Results of statistical analysis of all variables assessed}

This research was assessed in optimal cropping seasons (OCS) in 2010/2011 and dry cropping season (DCS) in 2011/2012. In order to evaluate in two cropping seasons, it was measured the same soybean agronomic traits in both cropping seasons (OCS and DCS), then the crop rotation affects and cropping seasons were studied in a joint analysis. Based on the results in ANOVA, it was observed that the crop rotation system did not affect ( $p>0.05)$ the plant height, height of the first pod insertion, number of stem per plant and soybean grain yield. However, the number of pod per plant and 1000-grain weight showed significant difference $(\mathrm{p} \leq 0.01)$ among the treatments (crop rotation system). With the exceptions of number of pod per plant and 1000-grain weight, the other soybean agronomic traits showed significant difference $(p \leq 0.01)$ in comparison between the cropping seasons. The interaction between crop rotation system and cropping seasons was obtained for 1000-grain weight.

\section{Plant height and height of the first pod insertion}

It was observed that in OCS the average of plant height was $1.03 \mathrm{~m}$, this height is in accordance to what is expected for soybean cultivar BMX-Potência RR cropped in the south region of Mato Grosso do Sul, Brazil. In DCS, the average of plant height was $0.71 \mathrm{~m}$, which was below the acceptable value $[0.96 \mathrm{~m}$ in average (Franchini et al., 2014) and $0.91 \mathrm{~m}$ in average (Rosa et al., 2015)]. Although, the plant height is determined by genetic control (Lee et al., 2015; Zhang et al., 2015), it is possible to infer that the environmental conditions, like rainfall may diminish the soybean height. This depletion observed in this research was $31.1 \%$ between the cropping seasons (Fig. 1). The rainfall in OCS was 1,017 $\mathrm{mm}$ and in DCS, the rainfall was just $752 \mathrm{~mm}$, this amount of rainfall is not enough to achieve great performance of plant growth. The soybean plant height might effect on its yield (Lee et al., 1996a, b; Chapman et al., 2003; Bizeti et al., 2004; Panthee et al., 2007), but this effect is dependent on other uncontrollable factors. It was observed that the correlation between plant height and soybean grains yield was moderate and positive ( $\mathrm{r}=0.410$ to 0.543 in OCS and DCS, respectively) (Table 1). This indicates that other factors influence the performance of soybean grain yield. The height of the first pod insertion did not show difference $(p>0.05)$ among the crop rotation system in both cropping seasons, but it was observed changes between the cropping seasons (Fig. 2). In OCS, the average height of the first pod insertion was $17.37 \mathrm{~cm}$ and DCS the average was $12.74 \mathrm{~cm}$. These values differed $(p \leq 0.05)$ between these cropping seasons. But in both results, the values are considered adequate for mechanical harvesting of soybean, because these values are above $12 \mathrm{~cm}$ (Ramteke et al., 2012). In OCS, the first pod height showed positive and moderate correlation $(\mathrm{r}=0.652)$ with soybean grain yield (Table 1). Although, Ramteke et al. (2012) observed weak correlation between the first pod insertion and soybean grain yield, they noticed that higher soybean grain yield was associated with genotypes that showed height of the first pod insertion above $12 \mathrm{~cm}$. The height of the first pod insertion in soybean is quite important because of the height of mechanical harvesting. In order to have great harvesting performance, it is essential that the soybean shows in flat topography height of the first pod insertion between 10 to $12 \mathrm{~cm}$, and in sloping land these values should be over than $15 \mathrm{~cm}$ (Cunha et al., 2013). These heights are suggested to decrease the soybean grain loss. In accordance to Ramteke et al. (2012), the first pod height must be at least $12 \mathrm{~cm}$ to avoid loss in grain yield during the mechanical harvesting of soybean.

\section{Crop rotation systems affect the number of pod per plant}

The cropping seasons did not influence $(\mathrm{p}>0.05)$ the number of pod per plant, this way, it was calculated the average value between the OCS and DCS to remain just one mean value in each treatment to proceed the Tukey test of means (Fig 3). The number of pod per plant ranged from 51 in crop rotation1 (soybean/set-aside area/soybean) to 77 in crop rotation-6 (corn/rapeseed/soybean) (Fig 3). Although no difference was observed for crop rotation system effects on soybean grain yield, it is important to emphasize that the absence of crop rotation resulted in the smallest number of pod per plant (Fig 3 ). It was possible to observe that the number of pod per plant showed strong correlation $(\mathrm{r}=0.750)$ with soybean yield (Table 1). In case of field experimentation, it is well-known that many other factors are associated with the crop production, thus this correlation is considered strong. As reported by El-Badawy and Mehasen (2012), the number of pod per plant was the phenotypic trait that influenced more in soybean grain yield, which showed strong and positive correlation $(\mathrm{r}=0.852)$. This trend was detected in this research, among the soybean agronomic traits evaluated, it was observed the highest correlation for number of pod per plant and soybean grain yield $(\mathrm{r}=0.750)$. As recorded by Sarutayophat (2012), the number of pod per plant if significantly associated with soybean grain yield, then this phenotypic trait is quite important for the selection of soybean genotypes. But, in some cases this phenotypic feature is weakly associated, as the case of Pedersen and Lauer (2004), who found weak and positive correlation $(\mathrm{r}=0.28)$ between soybean grain yield and number of pod per plant.

\section{Number of branches per plant and 1000-grain weight of soybean}

In relation to the number of branches per plant, the crop rotation system did not influence in this phenotypic trait 
Table 1. Correlation matrix of dependent variable.

\begin{tabular}{|c|c|c|c|c|c|c|}
\hline & \multicolumn{6}{|c|}{------------------ 2010/2011 Growing season --------------------- } \\
\hline & HS & HFPI & NBP & NPP & 1000-GW & SGY \\
\hline HS & 1 & 0.289 & 0.345 & 0.433 & -0.129 & 0.543 \\
\hline HFPI & & 1 & 0.750 & 0.387 & 0.706 & 0.652 \\
\hline NBP & & & 1 & 0.468 & 0.382 & 0.529 \\
\hline NPP & & & & 1 & 0.357 & 0.748 \\
\hline 1000-GW & & & & & 1 & 0.351 \\
\hline \multirow[t]{3}{*}{ SGY } & & & & & & 1 \\
\hline & \multicolumn{6}{|c|}{ 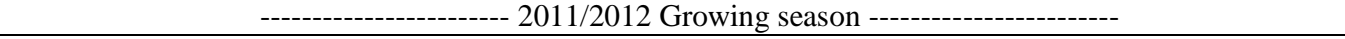 } \\
\hline & HS & HFPI & NBP & NPP & 1000-GW & SGY \\
\hline HS & 1 & -0.120 & 0.408 & 0.518 & 0.145 & 0.410 \\
\hline HFPI & & 1 & -0.262 & 0.293 & 0.517 & 0.127 \\
\hline NBP & & & 1 & -0.288 & 0.258 & -0.104 \\
\hline NPP & & & & 1 & 0.053 & 0.748 \\
\hline $1000-\mathrm{GW}$ & & & & & 1 & 0.500 \\
\hline SGY & & & & & & 1 \\
\hline
\end{tabular}

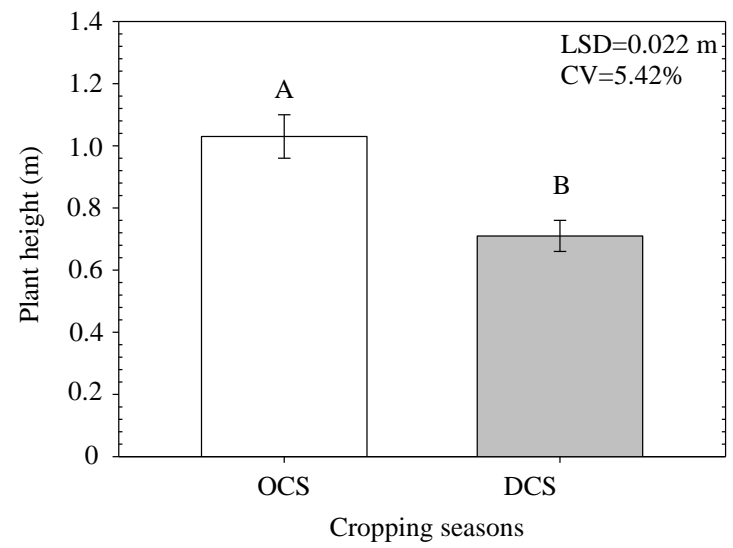

Fig 1. Plant height $(\mathrm{m})$ of soybean between cropping seasons, optimal cropping season (OCS) and dry cropping season (DCS). Mean in each bar followed by the same capital letter are not significantly different at 0.05 probability level by LSD (Least significant difference).

. Jug et al. (2012) observed that several crop rotation systems did not change the number of branches per plant. In relation to the cropping seasons, the number of branches differed significantly (Fig 4). Although, the number of branches is a trait defined by plant genetic, as reported by Kumar et al. (2015), there are several factors that impact on this plant trait. The number of branches is quite influenced by intraspecific plant competition. However, soybean plant adjusts to the population, with the increase of plant competition the number of branches decreases and the opposite is true (Hosseini et al., 2001; Mehmet, 2008). The correlation between number of branches per plant and soybean grain yield showed weak in both cropping seasons (Table 1), as it was reported by Kumar et al. (2015).

In the results of this experiment, it was observed that in drought stress (dry cropping season), the number of branches decrease in response to water limitation for growth, this reduction was $36 \%$ (Fig. 4). In condition of drought stress in soybean, Mirakhori et al. (2009) observed a decrease in the number of branches per plant, as well as plant height, number of pod per plant and soybean grain yield.

\section{Cropping seasons and crop rotation changed the soybean grain yield}

In relation to 1000 -grain weight, it was not observed changes ( $p>0.05$ ) among crop rotations evaluated. But it was observed significant $(\mathrm{p} \leq 0.01)$ effect for interaction between crop rotation system and cropping seasons (OCS and DCS) (Fig 5). In OCS and DCS, the 1000-grain weight ranged from 162 to $168 \mathrm{~g}$ and 142 to $149 \mathrm{~g}$, respectively. The average 1000 grain weight was $165 \mathrm{~g}$ and $145 \mathrm{~g}$ in OCS and DCS, respectively. These results showed significant difference $(p \leq 0.05)$ between cropping seasons (Fig 5). The best result for OCS was because of the favorable weather condition, especially the rainfall. This appointment was observed by Popović et al. (2012) as well, who worked in two cropping seasons and observed that higher rainfall contributes for a higher 1000-grain weight in the second cropping season (year 2010). As reported by them, the variable 1000 -grain weight did not differ among the four soybean cultivar tested, and in comparison to two cropping seasons (2009 and 2010) there was significant difference on average of 1000-grain weight, which ranged from $127.90 \mathrm{~g}$ to $161.99 \mathrm{~g}$. The 1000-grain weight is a quite important soybean grain yield component, especially for breeding process (Cunha et al., 2013). The correlation between 1000-grain weight and grain yield showed positive and moderate $r=0.351$ in OCS and $r=0.50$ in DCS (Table 1). Usually is observed high correlation between 1000 -grain weight and soybean grain yield, as it was found by El-Badawy and Mehasen (2012) that found strong correlation $(r=0.852)$ between this trait and soybean grain yield. The soybean grain yield did not differ among the treatments of crop rotation system ( $p>0.05$ ), this way, it was 
Table 2. Some soil chemical properties from the experimental area.

\begin{tabular}{lcc}
\hline & \multicolumn{2}{c}{ Depth $(\mathrm{cm})$} \\
\cline { 2 - 3 } $\mathrm{pH}\left(\mathrm{CaCl}_{2}\right)$ & $0-20$ & $20-40$ \\
$\mathrm{CEC}$ & 5.2 & 4.9 \\
$\mathrm{P}\left(\mathrm{mg} \mathrm{dm}^{-3}\right)$ & 11.4 & 5.8 \\
$\mathrm{Al}^{3+}\left(\mathrm{mmol}_{\mathrm{c}} \mathrm{dm}^{-3}\right)$ & 12.4 & 1.9 \\
$\mathrm{~K}^{+}\left(\mathrm{mmol}_{\mathrm{c}} \mathrm{dm}^{-3}\right)$ & 0.9 & 4.1 \\
$\mathrm{Ca}^{2+}\left(\mathrm{mmol}_{\mathrm{c}} \mathrm{dm}^{-3}\right)$ & 2.5 & 0.7 \\
$\mathrm{Mg}^{2+}\left(\mathrm{mmol}_{\mathrm{c}} \mathrm{dm}^{-3}\right)$ & 5.5 & 2.4 \\
$\mathrm{H}+\mathrm{Al}\left(\mathrm{mmol}_{\mathrm{c}} \mathrm{dm}_{-3}\right)$ & 1.6 & 0.9 \\
$\mathrm{BS}(\%)$ & 1.7 & 1.9 \\
\hline $\mathrm{CEC} \cdot$ Cation Exchange Capacity; total acidity $\mathrm{pH} 7.0\left(\mathrm{H}^{+}+\mathrm{Al}^{3+}\right)$ Exchangeable $\left(\mathrm{KCl} 1 \mathrm{~mol} \mathrm{~L}^{-1}\right) \mathrm{Ca}^{2+} \mathrm{Mg}^{2+}$ and Al ${ }^{3+}$. BS: Base Saturation= $=\left(\sum\right.$ cations/CEC $) \times 100$
\end{tabular}

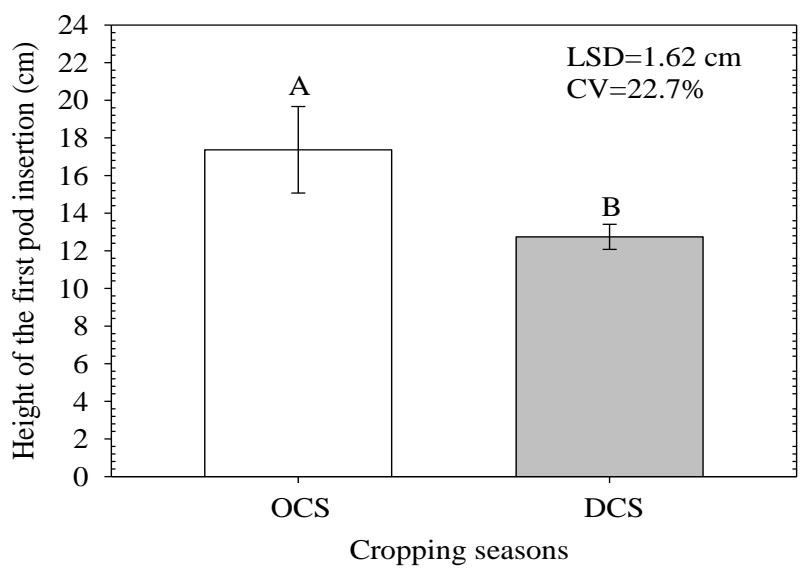

Fig 2. Height of the first pod insertion $(\mathrm{cm})$ of soybean between cropping season, optimal cropping season (OCS) and dry cropping season (DCS). Mean in each bar followed by the same capital letter are not significantly different at 0.05 probability level by LSD (Least significant difference).

studied just the cropping seasons effects on soybean grain yield, which showed significant changes $(\mathrm{p} \leq 0.05)$ (Fig. 6). The average soybean grain yield in OCS was $3,573 \mathrm{~kg} \mathrm{ha}^{-1}$ and $2,298 \mathrm{~kg} \mathrm{ha}^{-1}$ in DCS. The average soybean grain yield in the region of this research was $2,937 \mathrm{~kg} \mathrm{ha}^{-1}$ in 2010/2011 cropping season and 2,656 kg ha ${ }^{-1}$ in 2011/2012 cropping season. It was possible to infer that the soybean grain yield obtained in this research was adequate for the region, what reassure that these cover crops did not diminish the development of soybean. In OCS, all traits of soybean were correlated with soybean grain yield (Table 1). The correlation between the traits was positive and ranges from moderate to strong. On the other hand, in DCS, most of the traits showed weak and moderate correlation (Table 1). It was observed that other factors were influenced in the response of soybean grain yield in DCS. The drought stress can decrease the nutrient uptake by plant even with the optimal content of them in soil (Marschner, 1995), this way it is possible that nutrients limitation might influence in that growth and consequently in soybean grain yield. For both cropping seasons, the agronomic trait, number of pod per plant was strong $(r=0.748)$ and moderate $(r=0.666)$ associated with soybean grain yield, in OCS and DCS, respectively.The explanation for the soybean grain yield difference between the cropping seasons was related to the favorable weather condition in the region of the experiment in OCS, especially higher rainfall (Fig 7). In OCS, the rainfall was $1,017 \mathrm{~mm}$ and $752 \mathrm{~mm}$ in DCS (Fig 7). In OCS, the rainfall was more consistent during the vegetable and breeding stage of soybean (Fig 7). The drought stress in the vegetable stage was registered in the first ten-days period of October, first and third ten-days period of November in 2010/2011 (DCS), and with average of $73 \mathrm{~mm}$ of rainfall (Fig 7), it was not enough for the need of the plant growth. The soybean needs water ranged from 7 to $8 \mathrm{~mm} \mathrm{dia}^{-1}$. This drought stress in 2011/2012 (DCS) diminish the results of soybean for the traits of plant height, first pod height, 1000-grain weight and grain yield. The drought condition happened in the first, second and tenth-day of December 2011 (in the beginning of the bloom), in the first ten-days of January 2012 (pod full developed) (Fig 7). As reported by Confalone and Dujmovich (1999), the drought stress at the end of breeding stage (R4R6) and fill pod can damage drastically the soybean grain yield (Moran et al., 1994). Drought stress associated with high temperature during the grain fillers stage promote physiologic alteration in plant (Wang et al., 2003), as stomata close and leaves enrollment, and as consequence the plant stop the fixation of $\mathrm{CO}_{2}$ which infers negatively in photosynthesis process, decreasing the carbohydrate translocation, what affects the grain fillers, 1000-grain weight and soybean grain yield.

\section{Materials and Methods}

\section{Site and soil description}

This research was carried out in 2010/2011 and 2011/2012 cropping seasons in a Rhodic Hapludox, clayey texture, clay mineralogy constituted mainly by $\mathrm{Al} / \mathrm{Fe}$ oxy-hydroxides, classified according to Santos et al. (2013), located in the municipality of Dourados, state of Mato Grosso do Sul,

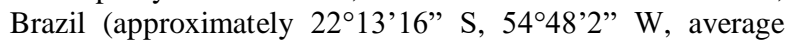
altitude $430 \mathrm{~m}$ above sea level). Before the establishment of the experiment, in October 2009, some soil chemical and 
Table 3. Sequence of treatments ${ }^{1}$ of crop rotation systems for fall-winter cover crops and the soybean and corn as major crop in spring-summer season.

\begin{tabular}{|c|c|c|c|c|c|}
\hline \multirow{3}{*}{$\begin{array}{l}\text { Crop rotation system } \\
\text { (Abbreviation) }\end{array}$} & \multicolumn{5}{|c|}{ Cropping seasons } \\
\hline & $2009 / 10$ & 2010 & $2010 / 11$ & 2011 & $2011 / 12$ \\
\hline & Spring-Summer & Fall-winter & Spring-summer & Fall-winter & Spring-summer \\
\hline S-S-S & Soybean & Set-aside area & Soybean & Set-aside area & Soybean \\
\hline S-C-S & Soybean & Corn & Soybean & Corn & Soybean \\
\hline S-B-S & Soybean & Corn + Brachiaria & Soybean & Corn + Brachiaria & Soybean \\
\hline C-W-S & Soybean & Sunflower & Corn & Wheat & Soybean \\
\hline C-S-S & Soybean & Rapeseed (Brassica napus L.) & Corn & Sunflower & Soybean \\
\hline C-T-S & Soybean & Carthamus tinctorius L. & Corn & Forage turnip & Soybean \\
\hline C-C-S & Soybean & Níger (Guizottia abyssinica) & Corn & Crambe & Soybean \\
\hline $\mathrm{C}-\mathrm{N}-\mathrm{S}$ & Soybean & Corn & Corn & Níger (Guizottia abyssinica) & Soybean \\
\hline C-W-S & Corn & Wheat & Soybean & Rapeseed (Brassica napus L.) & Corn \\
\hline C-S-S & Corn & Sunflower & Soybean & Wheat & Corn \\
\hline C-R-S & Corn & Rapeseed (Brassica napus L.) & Soybean & Sunflower & Corn \\
\hline C-T-S & Corn & Forage turnip & Soybean & Corn & Corn \\
\hline $\mathrm{C}-\mathrm{N}-\mathrm{S}$ & Corn & Níger (Guizottia abyssinica) & Soybean & Crambe & Corn \\
\hline
\end{tabular}

${ }^{1}$ In bold font is indicating the crop rotation systems used in this research. The evaluation of soybean performance was applied using the same crop rotations as indicated in the abbreviation in the table.

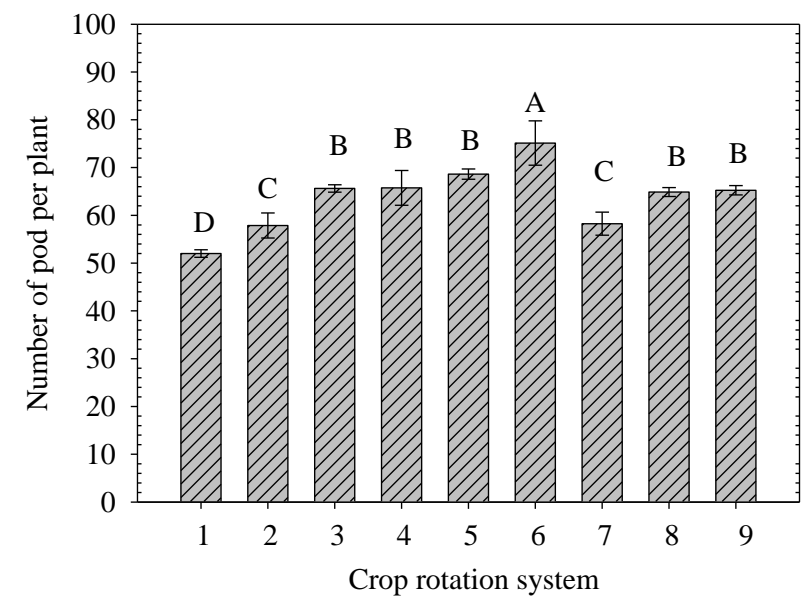

Fig 3. Crop rotation system effects on number of pod per plant. Mean in each bar followed by the same capital letter are not significantly different at $\mathrm{p} \leq 0.05$ according to Tukey test of mean. 1_Soybean/set-aside area/soybean; 2_soybean/corn/soybean; 3_soybean/corn+Brachiaria/soybean; 4_corn/wheat/soybean; $\quad$ 5_corn/sunflower/soybean; 6_corn/rapeseed/soybean; 7_corn/turnips/soybean; 8_corn/crambe/soybean; 9_corn/niger/soybean.

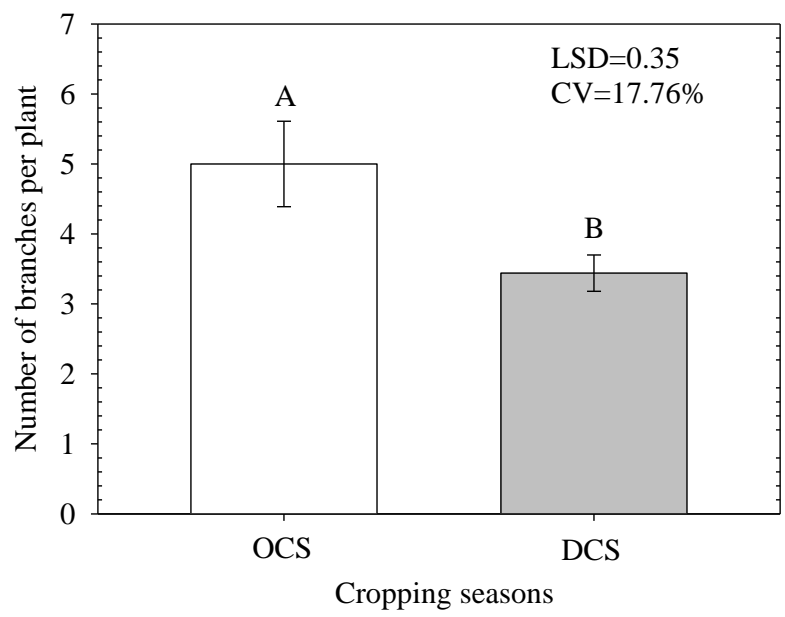

Fig 4. Cropping seasons [optimal cropping season (OCS) and dry cropping season (DCS)] affect on number of branches per plant. Mean in each bar followed by the same capital letter are not significantly different at 0.05 probability level by LSD (Least significant difference). 


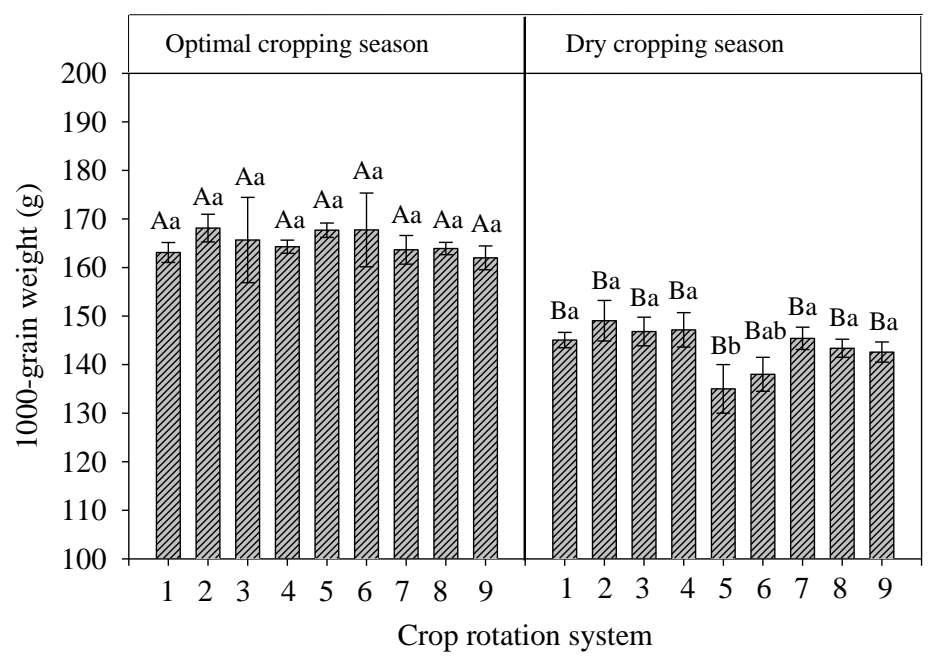

Fig 5. 1000-grain weight of soybean in response to the crop rotation system evaluated and two cropping seasons, optimal cropping season (OCS) and dry cropping season (DCS). Mean in each bar followed by the same low case letter are not significantly different at $\mathrm{p} \leq 0.05$ according to Tukey test of mean in each cropping season. Mean in each bar followed by the same capital letter are not significantly different at $\mathrm{p} \leq 0.05$ according to $F$-value between cropping seasons. 1_Soybean/set-aside area/soybean; 2_soybean/corn/soybean; 3_soybean/corn+Brachiaria/soybean; 4_corn/wheat/soybean; 5_corn/sunflower/soybean; 6_corn/rapeseed/soybean; 7_corn/turnips/soybean; 8_corn/crambe/soybean; 9_corn/niger/soybean.

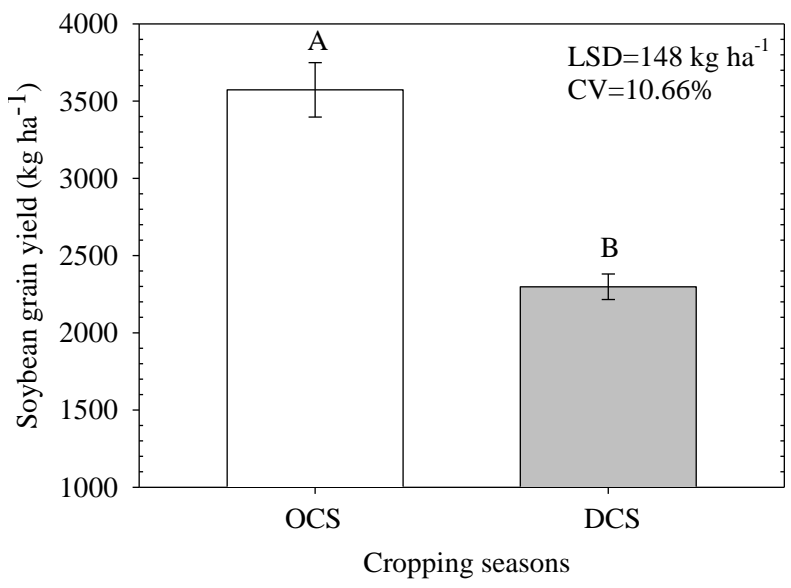

Fig 6. Cropping seasons [optimal cropping season (OCS) and dry cropping season (DCS)] effect on soybean grain yield (kg ha ${ }^{-1}$ ). Mean in each bar followed by the same capital letter are not significantly different at 0.01 probability level by LSD (Least significant difference).

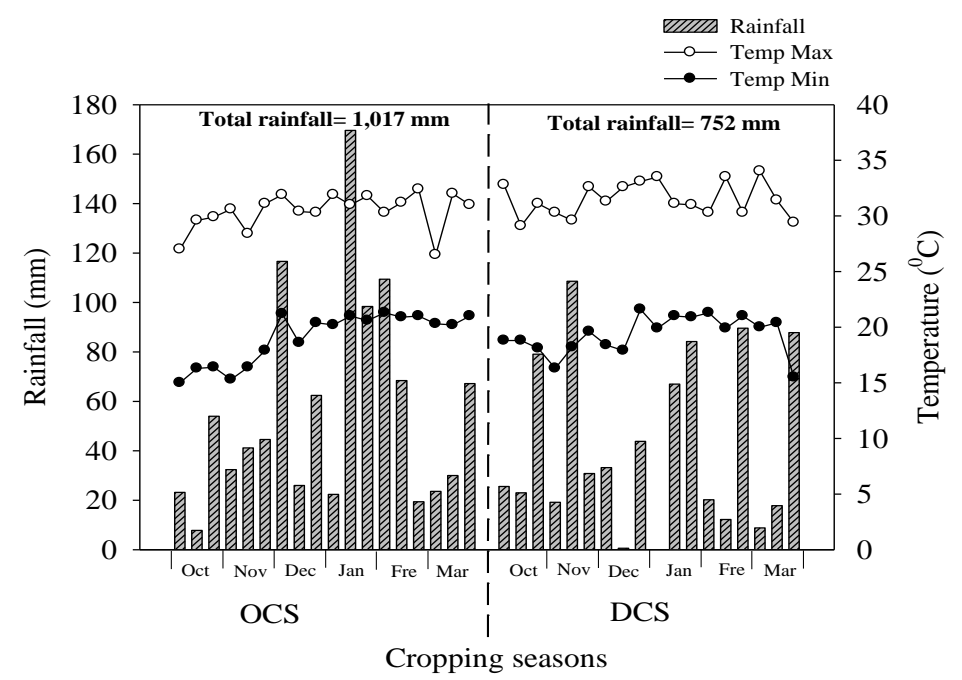

Fig 7. Rainfall, maximum and minimum temperature by each 10 days in the period from October to March in two growing seasons, optimal cropping season (OCS) and dry cropping season (DCS). Data from meteorological station of Universidade Federal da Grande Dourados (UFGD), Dourados city, in Brazil. 
physical properties were analyzed from $0-20$ and $20-40 \mathrm{~cm}$ depth (Table 2). The analysis showed the following results: 531,249 and $220 \mathrm{~g} \mathrm{~kg}^{-1}$ of clay, silt and sand respectively, according to Claessen (1997).

\section{Weather condition in the experimental site}

The data of rainfall and temperature in the experimental site are showed in Fig. 7. The period of weather condition data was during 2010/2011 and 2011/2012 cropping seasons, respectively optimal cropping season (OCS) and dry cropping season (DCS). According to Köppen (1948), the region is classified as tropical climate of type $\mathrm{Cwa}$, with rainy summer and dry winter.

\section{Historic of the experimental area}

Before the implementation of the experiment, the experimental site was cultivated with soybean in springsummer and corn crop in fall-winter season under no-till system. Based on the results of soil chemical (Table 2), in September 2009, it was applied 4,000 kg ha ${ }^{-1}$ of liming in the whole experimental area. The dolomitic lime showed calcium carbonate equivalent (CCE) of $80 \%$ (33\% calcium oxide and $15 \%$ magnesium oxide). The lime was incorporated with disk harrow of 32 inches. Right after the lime incorporation, it was applied gypsum $\left(2,000 \mathrm{~kg} \mathrm{ha}^{-1}\right)$ incorporated with leveling disk harrow of 22 inches.

\section{Experimental design and treatments}

The experimental design was set up in a randomized complete block design and the treatments were arranged in a factorial arrangement $9 \times 2$, consisting of 9 crop rotations system (Table 3 ) and two cropping seasons (OCS and DCS), with four replications. The experimental units had dimensions of $15 \mathrm{~m}$ length by $35 \mathrm{~m}$ width $\left(525 \mathrm{~m}^{2}\right)$. All operations were executed with a tractor wheel of $112 \mathrm{HP}$ (Horsepower). For the seeding procedure it was used grain drill with the rows spaced $45 \mathrm{~cm}$ apart for planting soybean. The treatments are showed in the Table 3, which is related to different cover crops assessed in a crop rotation system. These cover crops are fall-winter crops species, all of them were sowed in the fall-winter season, right after the soybean harvest. The crop rotation system S-S-S, S-C-S and S-B-S were compiled by soybean/set-aside area/soybean, soybean/corn/soybean and soybean/intercropping (corn+ Brachiaria)/soybean, respectively (Table 3). The other treatments of crop rotation system were corn or soybean in spring-summer and fall-winter crop rotations were compiled by gramineas and oilseed, C-W-S, C-S-S, C-R-S, C-T-S, CC-S and C-N-S (Table 3).

\section{Plant material and measurement}

The soybean (Glycine max cv. BMX-Potência RR) was established in crop rotation to be feasible the implementation of a no-till system. The cover crops were planted to produce above-ground dry matter to make part of a crop rotation system. The soybean was sowed on October $20^{\text {th }} 2010$ and October $10^{\text {th }} 2011$ right after the fall-winter cover crops desiccation. The seed density of soybean was 15 seeds per meter and the dose of fertilizer was $\mathrm{N}=6, \mathrm{P}_{2} \mathrm{O}_{5}=60, \mathrm{~K}_{2} \mathrm{O}=60$, $\mathrm{Zn}=0.9$ and $\mathrm{B}=0.9 \mathrm{~kg} \mathrm{ha}^{-1}$. The fertilizer was applied in line of seeding, with $8 \mathrm{~cm}$ depth, which was allocated under and apart the seed to avoid contact.
The soybean (BMX-Potência RR) was sowed after 20 days from the cover crops desiccation, which was accomplished with the herbicide glyphosate $\left(1,296 \mathrm{~kg}\right.$ e.a. ha $\left.{ }^{-1}\right)$. The soybean germination and purity of the seed were 95 and $99 \%$, respectively. The seed density was 15 seeds per meter and resulted in plant stand of 316,664 plants per hectare. In the R8 reproductive stage (Full maturation), it was determined the plant height, the height of the first pod insertion, number of pod per plant, number of branches per plant, number of seed per pod, 1000-grain weight and yield were evaluated. The soybean grain yield was measured by the manual harvest in the experimental unit in a dimension of $5 \mathrm{~m}$ by $0.9 \mathrm{~m}$ in the center of each experimental unit. The grains were weighted and the yield was showed in $\mathrm{kg} \mathrm{ha}^{-1}$.

\section{Statistical analysis}

The variables evaluated in this experiment were submitted to the analysis of variance (ANOVA) by the $F$-test. The averages were compared by the Tukey's test of mean at 0.05 levels, in case with more than two means. Least statistic difference (L.S.D.) test at 0.05 levels was used for comparison between means, in case with just two means. These tests were carried out with the use of Assistat software (Silva and Azevedo, 2002).

\section{Conclusion}

The drought stress in dry cropping season (DCS) influenced negatively the soybean performance. The rainfall of $752 \mathrm{~mm}$ was not enough to achieve great performance of soybean. On the other hand, in optimal cropping season (OCS), the rainfall of $1,017 \mathrm{~mm}$ was enough to achieve great performance of soybean. This way, for the traits; plant height, first pod height, 1000-grain weight and grain yield, it was showed small values in DCS. Based on the results obtained, it was possible to conclude that the crop rotation system used in this research did not influence negatively on any soybean traits and soybean grain yield in both OCS and DCS. It infers that it is feasible to introduce these cover crops in fall-winter season to make part of a crop rotation system. The number of pod per plant showed higher values under the crop rotation of corn/rapeseed/soybean, which showed highly associated with the soybean grain yield. Although, no statistic difference was observed among the crop rotation in relation to the set-aside area for soybean grain yield, it is important to keep in mind that the use of cover crops can bring economic funds and contribute to the benefits of physical, chemical and biological soil features over the years, because in no-till system it is not possible to remain viable without cover crops. This research brought options for cover crops system to be viable in no-till system with soybean in spring-summer season.

\section{Acknowledgement}

The authors are grateful to Universidade Federal Grande da Dourados (UFGD) for the collaborations of researchers and CNPq (National Council for Scientific and Technological Development $\mathrm{CNPq}$ ) for the financial support to the accomplishment of this work.

\section{References}

Anderson RL (2015) Integrating a complex rotation with notill improves weed management in organic farming: A review. Agron Sustain Dev. 35: 967-974. 
Argenta G, Silva PRF, Fleck NG, Bortolini CG, Neves R, Agostinetto D (2001) Effects of mechanical and chemical management of black oat on maize grown in succession and on alexander grass control. Pesqui Agropecu Bras. 36(6): 851-860.

Bizeti HSA, Carvalho P, Souza CGB, Pinto JRA, Destro DA (2004) Path analysis under multi collinearity in soybean. Braz Arch Biol Techn. 47(5): 669-676.

Chapman A, Pantalone VR, Ustun A, Allen FL, LandauEllis D, Trigiano RN, Gresshoff PM (2003) Quantitative trait loci for agronomic and seed quality traits in an F2 and F4:6 soybean population. Euphytica. 129: 387-393.

Claessen, MEC (Org.) (1997) Manual de métodos de análises de solo. 2.ed. revisão atualizada. Rio de Janeiro: Embrapa Solos, 212p.

Confalone A, Dujmovich MN (1999) Influência do déficit hídrico sobre o desenvolvimento e rendimento da soja. Rev Bras Agrom. 7: 183-187.

Congreves KA, Hayes A, Verhallen EA, Van LL (2015) Long-term impact of tillage and crop rotation on soil health at four temperate agroecosystems. Soil Till Res. 152: 17-28.

Cunha MCG, Hamawaki OT, Sousa LB (2013) Genetic variability among 79 soybean progenies from ufu breeding program. Biosci J. 29(2): 340-349.

Dumanski J. (2015) Evolving concepts and opportunities in soil conservation. Int Soil Water Conserv Res. 3: 114.

El-Badawy MEM, Mehasen SAS (2012) Correlation and path coefficient analysis for yield and yield components of soybean genotypes under different planting density. Asian J Crop Sci. 4(4): 150-158.

Fidelis RR, Rocha RNC, Leite VT, Tancredi FD (2003) Some aspects of no-tillage system on soilbean. Biosc J. 19(1): 23-31.

Franchini JC, Junior AAB, Debiasi H, Conte O (2014) Soybean performance as affected by desiccation time of Urochloa ruziziensis and grazing pressures. Rev Cienc Agron. 45(5): 999-1005.

Fraser PM, Curtina D, Harrison-Kirka T, Meenkena ED, Bearea MH, Tableya F, Gillespiea RN, Francis GS (2013) Winter nitrate leaching under different tillage and winter cover crop management practices. Soil Sci Soc Am J. 77(4): 1391-1401.

Harasim E, Gawęda D, Wesołowski M, Kwiatkowskia C, Gocóła M (2015) Cover cropping influences physicochemical soil properties under direct drilling soybean. Acta Agr Scand B-S P. 65: 853-86.

Hosseini NM, Ellis RH, Yazdi-Samadi B (2001) Effects of plant population density on yield and yield components of eight isolines of cv. Clark (Glycine max L.). Agric Sci Technol. 3: 131-139.

Jug D, Sabo M, Jug I, Stipešević B, Stošić M (2012) Effect of different tillage systems on the yield and yield components of soybean [ Glycine max (L.) Merr.]. Acta Agron Hung. 58(1): 65-72.

Köppen W (1948) Climatologia: con un estudio de los climas de la tierra. México: Fondo de Cultura Económica, 478p.

Kumar A, Pandey A, Aochen C, Pattanayak A (2015) Evaluation of genetic diversity and interrelationships of agromorphological characters in soybean (Glycine max) genotypes. Proc Natl Acad Sci. 85(2): 397-405.
Lee S, Jun TH, Michel AP, Mian MAR (2015) SNP markers linked to QTL conditioning plant height, lodging, and maturity in soybean. Euphytica. 203: 521532.

Lee SH, Bailey MA, Mian MAR, Shipe ER, Ashley DA, Parrott WA, Hussey RS, Boerma HR (1996a) Identification of quantitative trait loci for plant height, lodging, and maturity in a soybean population segregating for growth habit. Theor Appl Genet 92: 516-523.

Lee SH, Bailey MA, Mian MAR, Carter TE, Ashley DA, Hussey RS, Parrott WA, Boerma HR (1996b) Molecular markers associated with soybean plant height, lodging, and maturity across locations. Crop Sci. 36: 728-735.

Marschner H (1995) Mineral nutrition of higher plants. San Diego: Academic Press. 889p.

Mehmet OZ (2008) Nitrogen rate and plant population effects on yield and yield components in soybean. Afr J Biotechnol. 7 (24): 4464-4470.

Merten GH, Araújo AG, Biscaia RCM, Barbosa GMC, Conteb O. (2015) No-till surface runoff and soil losses in southern Brazil. Soil Till Res. 152: 85-93.

Mirakhori M, Paknejad F, Moradi F, Ardakani M, Zahedi H, Nazeri P (2009) Effect of drought stress and methanol on yield and yield components of soybean max (L 17). Am J Biochem Biotechnol. 5 (4): 162-169.

Moran JF, Becana M, Iturbe-Ormaetxe I, Frechilla S, Klucas RV, Aparicio-Teho P. (1994) Drought induces oxidative stress in pea plants. Planta. 194: 346-352.

Nichols V, Verhulst N, Cox R, Govaerts B (2015) Weed dynamics and conservation agriculture principles: A review. Field Crop Res. 183: 56-68.

Panthee DR, Pantalone VR, Saxton AM, West DR, Sams CE (2007) Quantitative trait loci for agronomic traits in soybean. Plant Breeding. 126: 51-57.

Pedersen P, Joseph G (2004) Response of soybean yield components to management system and planting date lauer. Agron J. 96: 1372-1381.

Popović V, Vidić M, Jocković Đ, Ikanović J, Jakšić S, Cvijanović G. (2012) Variability and correlations between yield components of soybean [Glycine $\max (\mathrm{L}$.) Merr.]. Genetika. 44(1): 33-45.

Ramteke R, Singh D, Murlidharan P (2012) Selecting soybean (Glycine $\max$ ) genotypes for insertion height of the lowest pod, the useful trait for combine harvester. Indian J Agr Sci. 82(6): 511-515.

Rosa CBCJ, Marchetti ME, Serra AP, Rosa MSM, Ensinas SC, Conrad VA, Altomar PH, Potrich DC, Martinez MA (2015) Short-term effects of lime management in soybean no-tillage system implementation in Brazilian savannah. Aust J Crop Sci. 9(3): 232-241.

Santos HG, Jacomine PKT, Anjos LHC, Oliveira VA, Lubreras JF, Coelho MR, Almeida JA, Cunha TJF, Oliveira JB. (ed.) 2013. Sistema Brasileiro de Classificação de Solos. 3. edição revisada e ampliada. Brasília: Embrapa, 353 p.

Sarutayophat T (2012) Correlation and path coefficient analysis for yield and its components in vegetable soybean. Songklanakarin J Sci Technol. 34 (3): 273 277.

Silva FASE, Azevedo CAV. (2002) Versão do programa computacional Assistat para o sistema operacional windows. Rev Bras Prod Agroind. 4(1): 71-78. 
TerAvest D, Carpenter-Boggs L, Thierfelder C, Reganold JP (2015) Crop production and soil water management in conservation agriculture, no-till, and conventional tillage systems in Malawi. Agric Ecosyst Environ. 212: 285-296.

Wang W, Vinocur B, Altman A (2003) Plant responses to drought, salinity and extreme temperatures: towards genetic engineering for stress tolerance. Planta. 218: 114.
Zhang J, Song Q, Cregan PB, Nelson RL, Wang X, Wu J, Jiang G (2015) Genome-wide association study for flowering time, maturity dates and plant height in early maturing soybean (Glycine max) germplasm. BMC Genomics. 16: 217-240. 